\title{
The College Students' Satisfaction for Using Edmodo - the Learning Technology Application as E-Learning Media and Learning Effectiveness Improvement in Economic Higher Institution Mahardika Surabaya
}

\author{
Susilowati; Asmirin Noor; Rustono; Samsudi; I Made Sudana; M.D. Kharis Rifai, S.Tr., M.M \\ Universitas Negeri Semarang. \\ susilowaticendekiaku@gmail.com.
}

\begin{abstract}
This is quantitative research. The purpose of this study was to reveal the use of Edmodo free learning applications on student satisfaction and learning effectiveness. The population of this study was students of the Mahardika Surabaya Economics College who took e-learning courses. While the sample is 160 students. Sampling was done by Non-Probability Sampling, namely by Accidental Sampling. The instrument used is in the form of a questionnaire. The data analysis used is path analysis. The results of the analysis prove that satisfaction has a significant effect on the effectiveness of learning. Student satisfaction affects the effectiveness of learning because they are satisfied with learning, service, and teaching. They can increase effectiveness, such as doing assigned assignments, presenting, studying, and discussing with colleagues or lecturers.
\end{abstract}

Keywords: Edmodo, Quantitative research, Path Analysis, Student satisfaction

\section{INTRODUCTION}

The ease of Internet uses influences all life aspects. In the educational world, Internet technology advancement brings to benefit learning technology development. According to Silber (1970), "Learning Technology refers to development (research, design, production, evaluation, support-supply, and use). The learning system components consist of message, individual, material, equipment, technique, and background. Business development management consists of organization and personal systematically based on the purpose to solve problems.

Internet technology is the most ideal media for distant learning activities. By using this learning technology application, classes will be more effective. The communication between lecturers and students will be easy. The tasks given by lecturers and their submissions done by college students will be more flexible. This technology also brings many benefits.

Internet technology development causes the educational system to shift from face-to-face education into a more flexible education. It also reduces the frequency of face-to-face learning (online with e-learning).

E-Learning is a learning approach connected via a computer in the form of PC, Laptop, Netbook, Tablet, and android-based mobile phone. They are also connected to the Internet and allow learners to obtain the appropriate learning materials for their needs. E-Learning is seen as a developed system in the effort to improve learning quality. It attempts to remove the gaps of spatial and time limitations (Deni Darmawan, 2012).

Handayani (2014) stated that the satisfaction levels of PalCOmTech portal student web users were significant. They were measured from the ease of use, customization, download delay, and content. Okatria (2015) stated there was learning influence by using e-learning media toward the college learning interest on the e-learning course. Taradipa, Siswandari, Sri Sumaryati (2013) found the influence of using combined learning media toward the college students' learning interest on Accounting Learning Technology Course.

In Economic Higher Institution Mahardika Surabaya, the learning process had been instructed to apply Moodle (Modular Object-Oriented Dynamic Learning Environment). The e-learning could be accessed via http://stiemahardhika-elearning.ac.id. However, both lecturers and the college students still used the Edmodo application as learning technology to interact not only among the students and the lecturers but also with the whole world lecturers.

Several benefits could be obtained while promoting E-learning, such as:

a. Cost efficiency 


\author{
b. Lecturer-Student Ratio \\ c. Time Flexibility \\ d. Wider range \\ e. Improving the IT skills of both lecturers and students
}

In this research, the researcher attempted to reveal the uses of the free-learning application, Edmodo, toward the students' satisfaction and the effectiveness of the learning.

Based on the background, the researchers formulated the research questions:

a. Did the Edmodo learning application influence the students of STIE Mahardika satisfaction?

b. Did the Emodo learning application influence the learning effectiveness of STIE Mahardika?

c. Did the students' satisfaction influence the learning effectiveness of STIE Mahardika?

\title{
2. LITERATURE REVIEW
}

\section{a. The Edmodo Learning Technology}

Edmodo is a secure learning platform for both teachers, students, and schools based on social media. Besides that, Edmodo also has similarities as Facebook does but Edmodo is more educative for the educational world. Edmodo has many features to promote learning. They can be used based on every teacher and student's needs. They are such as group, library, note, assignment, alter feature, etc. (Fitriasari: 2017)

Edmodo is a social network within a microblogging service. It is designed for an educational world that could be operated just like Twitter. By limiting access to the specific room or group, both teachers and students could send the notes, links, files, announcements, tasks, and information in a secured environment (Wankel, 2011:24).

Edmodo was developed in late 2008 by Nic Borg and Jeff Ohara. They believed in the importance of developing all-world-connected activity schools to remove the gaps between the learners' life and their daily life. Edmodo is a microblogging-social network media. It is secure for both teachers and students. On this site, parents could also join and communicate with the teachers, the students' parents, and the students. Edmodo has been significantly developed and already had more than 7 million accounts of teachers and students. In 2010, Edmodo launched a program, the community "subject" and "publisher"., library digital media, help center, and primary account to communicate among teachers, parents, and students (Kristiani: 2017)

Edmodo is a Learning Management System-based social network. Edmodo facilitates teachers and students in a secure room to communicate, collaborate; share content and learning application, homework; discuss virtually; conduct online daily examinations; assess, etc. The point is - Edmodo provides all activities that can be promoted together in the classroom with students. The special thing is parents could get involved to monitor the students as long as they obtain the parent code for the students. Edmodo is a cite for educators to create free and easy virtual class sites for parents and students, connected by the Internet.

Kurniabudi and Setiawan Assegaff (2016) found that performance expectancy, price value, and habit could significantly influence the intentional behavior of the Edmodo users during the course. However, on the other hand, the research found that effort expectancy, social influence, hedonistic motivation, and facilitation condition did not influence significantly the behavioral intention.

Several strengths of Edmodo are (Fitriasari: 2017) :

1. User Interface. Adapting the Facebook look modestly makes Edmodo relatively easy to use for beginners.

2. Compatibility. Edmodo supports the previews of any file format type, such as pdf, pptx, Html, swf, and so on.

3. Application Edmodo can be accessed via PC and Android OS-based gadgets.

The offered features by Edmodo are (Kristiani, 2017) : 
1. Editing Profile Picture and Name

2. It has the same look as Facebook.

3. Assignments could be posted by teachers as homework or tasks.

4. Regulating the important event schedules

5. A student can be a student for many teachers.

6. Accessible via handphone

\section{b. Students' Satisfaction}

According to Kotler, Lavenia et. al (2018), stated that customers' satisfaction was the levels of individuals' feelings after comparing (performance or results) from what they experienced to their expectations.

Several indicators of customer satisfaction are (Kotler and Keller: 2000) :

a. Re-purchase refers to a condition in which customers will buy again from the corporation to get the demanded goods or services.

b. Creating a word of mouth allows customers to judge the products or services excellently about the corporation toward other people.

c. Branding refers to a condition in which the corporation becomes the top of mind. Therefore, customers will not pay attention to the brand and the advertisement of the other competitors' products or services.

d. Deciding to purchase on the same corporation refers to a condition in which customers purchase other products but from the same corporation.

The students' satisfaction in this research dealt with the students' feelings after using the Edmodo application features than their expectations. The indicators are:

a. User interface satisfaction

b. Compatibility satisfaction

c. Application installation satisfaction

d. Complete feature satisfaction

\section{c. Learning Effectiveness}

According to the Indonesian dictionary, the word effectiveness means to have the effect or to cause something. The effectiveness is appropriateness between the individuals that carry the tasks with the targeted objectives and how an organization succeeds to obtain and use the resource in business. It is to create an operational objective.

According to Supardi (2013), effective learning is combined learning of human, material, facility, equipment, and procedure. They are directed to change the students' behaviors positively and better based on the potentials and differences of the students. They are all for the sake of the applied learning objectives.

According to Nuraeni (2010), the learning model was considered effective to improve the students' learning outcomes statistically. The students showed significant differences between the initial and the latest understanding (having significant N-gain).

According to The Coaching Team of Dikdaktik Metodik Course Curriculum of IKIP Surabaya (Trianto, 2010), the learning effectiveness in an excellent learning interaction process was all efforts of teachers to facilitate students' learning. A test was

given to find out the teaching effectiveness. The test results could be used to evaluate various teaching process aspects.

According to Surya (Agsha: 2015), learning program effectiveness is indicated by the following features:

1. Learning programs could bring the students to achieve the applied instructional objectives.

2. The learning program was attractive and involved learners actively. Thus, it could support the instructional objective achievement.

3. The learning program had to learn supportive facilities. 
The indicators were:

1. Outcome aspect

2. Process aspect

3. Learning Facility aspect

\section{METHODOLOGY}

This research is quantitative. According to Sugiyono (2018), a quantitative method is "A method based on positivism philosophy. It is applied in certain populations and samples. The data collection uses a research instrument. The data analysis is quantitative or statistics with the purposes to test the applied hypotheses."

In this research, the researcher attempted to reveal the uses of the free-learning application, Edmodo, toward the students' satisfaction and the effectiveness of the learning. The applied analysis was pat.

The population of this research consisted of the college students of Economic Higher Institution Mahardika Surabaya who joined courses with official e-learning Moodle of the campus and used the Edmodo learning technology application. One regular-morning class and three regular-evening classes had a total of 160 students. The sample was taken with Krjcie and Morgan's table from the sample of 113 individuals. A questionnaire was found not completely answered. Thus, there were only 112 respondents. The sampling technique was NonProbability Sampling with the Accidental Sampling approach.

\section{FINDINGS / RESULTS}

From the analysis results by the SPSS program, the analysis results obtained validity and reliability data as following:

\begin{tabular}{|c|c|c|c|c|c|}
\hline Variables & Indicators & $\begin{array}{c}\text { Pearson } \\
\text { Correlation }\end{array}$ & Remark. & $\begin{array}{c}\text { Cronbach's } \\
\text { Alpha }\end{array}$ & Remarks \\
\hline \multirow{4}{*}{$\begin{array}{l}\text { APLIKASI } \\
\text { EDMODO }\end{array}$} & Interface & 0.741 & Valid & \multirow[t]{4}{*}{0.794} & \multirow[t]{4}{*}{ Reliable } \\
\hline & Compatibility & 0.677 & Valid & & \\
\hline & Application & 0.745 & Valid & & \\
\hline & Fitur & 0.790 & Valid & & \\
\hline \multirow[t]{4}{*}{ SATISFACTIONS } & Interface & 0.858 & Valid & \multirow[t]{4}{*}{0.814} & \multirow[t]{4}{*}{ Reliable } \\
\hline & Compatibility & 0.858 & Valid & & \\
\hline & Application & 0.636 & Valid & & \\
\hline & Feature & 0.833 & Valid & & \\
\hline \multirow{3}{*}{$\begin{array}{l}\text { LEARNING } \\
\text { EFFECTIVENESS }\end{array}$} & Learning outcomes & 0.796 & Valid & \multirow[t]{3}{*}{0.831} & \multirow[t]{3}{*}{ Reliable } \\
\hline & Learning process & 0.850 & Valid & & \\
\hline & Learning Facility & 0.790 & Valid & & \\
\hline
\end{tabular}

From the table, all items of each variable were valid with a Pearson Correlation score, 0.3. All variables were variable with the Cronbach's Alpha score of 0.6.

From the analysis with SPSS, the first regression, based on the table, is

\section{Coefficients}

\begin{tabular}{|c|c|c|c|c|c|c|}
\hline \multirow{3}{*}{\multicolumn{2}{|c|}{ Model }} & \multicolumn{5}{|c|}{ Standardized } \\
\hline & & \multicolumn{2}{|c|}{ Unstandardized Coefficients } & Coefficients & & \multirow[b]{2}{*}{ Sig. } \\
\hline & & $\mathrm{B}$ & Std. Error & Beta & $\mathrm{t}$ & \\
\hline \multirow[t]{2}{*}{1} & (Constant) & 4,685 & 2.622 & \multirow[b]{2}{*}{.702} & 1.787 & .077 \\
\hline & $\begin{array}{l}\text { EDMODO } \\
\text { APPLICATION }\end{array}$ & .795 & .077 & & 10.329 & .000 \\
\hline
\end{tabular}

a. Dependent Variable: STUDENTS" SATISFACTION 
The second regression analysis results obtained a coefficient of

\section{Coefficients}

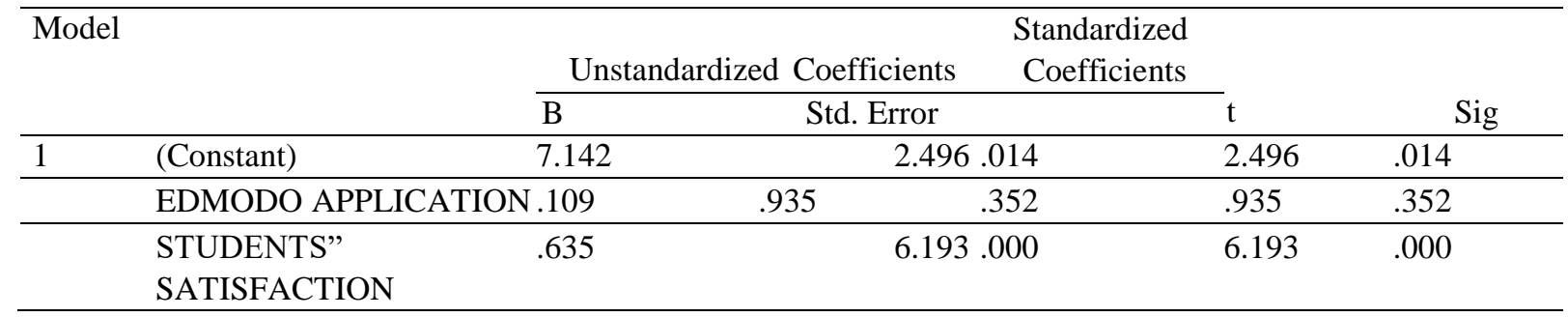

a. Dependent Variable: LEARNING EFFECTIVENESS

The analysis results with the AMOS program obtain:

Regression Weights: (Group number 1 - Default model)

\begin{tabular}{|c|c|c|c|c|c|c|}
\hline & & Estimate & S.E. & C.R. & $\mathrm{P}$ & Label \\
\hline Satisfaction & Edmodo_Application & ,795 & ,077 & 10,376 & $* * *$ & par_1 \\
\hline Effectiveness <--- & Edmodo_Application & , 109 &, 115 & ,944 & ,345 & par_2 \\
\hline Effectiveness <--- & Satisfaction & 635 & ,102 & 6,250 & $* * *$ & par_3 \\
\hline
\end{tabular}

Indirect influence

Indirect Effects (Group number 1 - Default model)

\begin{tabular}{lrc}
\hline & Edmodo_Application & Satisfaction \\
\hline Satisfaction &, 000 &, 000 \\
Effectiveness &, 505 &, 000 \\
\hline
\end{tabular}

The diagram representing the results in the Table is shown below:

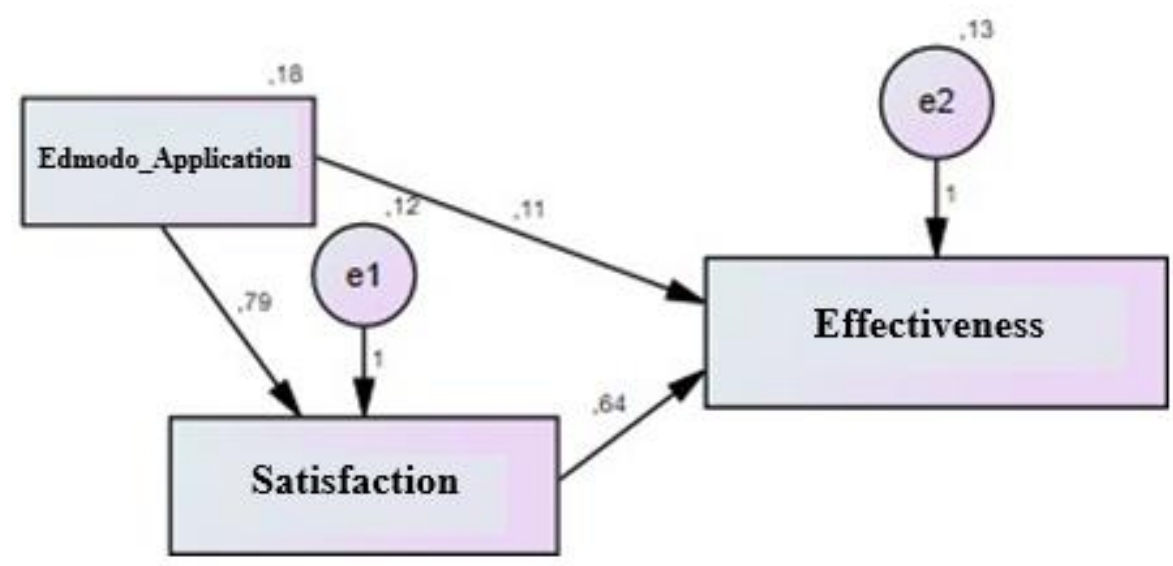

\section{DISCUSSION}

Edmodo Application toward Satisfaction 
The analysis results proved that Edmodo Application significantly influenced the students' satisfaction. It was proven with a probability score of 0.000 , lesser than 0.05 . It showed that proper Edmodo implementation would improve students' satisfaction in teaching-learning activities.

It was in line with Sudarsi's research about the effectiveness of Edmodo implementation toward the students' satisfaction of Public VHS 1 Surabaya. He found that the use of Edmodo positively influenced the students' satisfaction. All effectiveness indicators of using Edmodo influenced their satisfaction to apply it.

The use of Edmodo for college students' learning significantly influenced them to join distance learning. All course materials could be delivered with Edmodo. Thus, face-to-face courses were not needed. The students had a spirit to learn using Edmodo because of its interesting features. The features could relieve the students' boredom. Thus, the students' satisfaction got higher while using Edmodo.

\section{Edmodo Application toward Learning Effectiveness}

The analysis results proved that Edmodo Application significantly influenced the students' Learning Effectiveness It was proven with the probability score of 0.345 , lesser than

0.05. It showed that Edmodo could not improve the learning effectiveness interest because the students had been habituated to learn face-to-face. Thus, several students that did not understand to learn by using Edmodo. Therefore, it did not influence significantly the students' effectiveness improvement especially for the postgraduate students because they were older than 35 years old. Thus, they had difficulties using the application.

\section{Satisfaction toward the learning effectiveness}

The analysis result proved that satisfaction significantly influenced the learning effectiveness. It was proven by the probability score, 0.000 , lesser than 0.05 . It showed that students' satisfaction influenced the learning effectiveness. It meant excellent students' satisfaction led to more active and creative learning.

The students' satisfaction influenced the learning effectiveness because they were satisfied with the learning, service, and lecturer. They could improve the effectiveness, such as by working on the given task, presenting, learning, and discussing with peers or lecturers.

\section{REFERENCES}

1. Ainiyah, Z. (2015). Penggunaan Edmodo sebagai Media Pembelajaran Online pada Mata Pelajaran $\begin{array}{llllll}\text { Otomatisasi Perkantoran di SMKN } 1 & \text { Surabaya. Tersedia: }\end{array}$ http://ejournal.unesa.ac.id/article/16278/55/article.pdf. [10 November 2016]

2. Darmawan, Deni. (2012). Inovasi Pendidikan. Bandung : PT Remaja Rosdakary

3. Dwiharja, L.M. (2015). Memanfaatkan Edmodo sebagai Media Pembelajaran Akuntansi. [Online]. Tersedia: http://eprints.uny.ac.id/21919/1/32\%20Laksmi\%20Mahendrati\%20 Dwiharja.pdf. [10 November 2016]

4. Fitriasari, Putri. (2017). Aplikasi Edmodo Sebagai Media Pembelajaran E-Learning. Proceeding. Universitas PGRI Palembang. Indonesia

5. Kotler, P., dan, K. L. Keller. (2000). Manajemen Pemasaran 301

6. Kristiani, Dwi. 2017. E-Learning Dengan Aplikasi Edmodo di Sekolah Menengah Kejuruan Kustandi, C. dan Bambang S. (2011). Media Pembelajaran; Manual dan Digital. Bogor: Penerbit Ghalia Indonesia.

7. Lavenia, B. C., Iqbal, M., dan A., Irawan. (2018). Pengaruh Technology Acceptance Model (TAM) dan Electronic Word Of Mouth (EWOM) Terhadap Kepuasan Pelanggan. Jurnal Administrasi Bisnis

$(J A B), \quad 60(3), \quad 52-61$. Retrieved from administrasibisnis.studentjournal.ub.ac.id

8. Sugiyono. (2018). Metode Penelitian Pendidikan Pendekatan Kuantitatif, kualitatif, dan R\&D. Bandung: Alfabeta.

9. Supardi. (2013). Sekolah Efektif, Konsep Dasar dan Praktiknya. Jakarta: Rajawali Pers,

10. Yunus, F. (2013). Edmodo untuk Aplikasi Pembelajaran Kolaboratif. [Online]. Tersedia: http://www.edmodo.com/file/view-crocodoc-new-window?uuid= de949a0b-0b9a-43c7- 9fca85447ce6036f. [12 November 2016] 